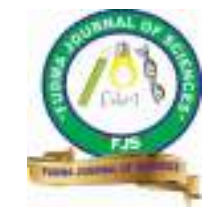

FUDMA Journal of Sciences (FJS)

ISSN online: $2616-1370$

ISSN print: 2645 - 2944

Vol. 5 No. 1, March, 2021, pp $495-501$

DOI: https://doi.org/10.33003/fjs-2021-0501-595

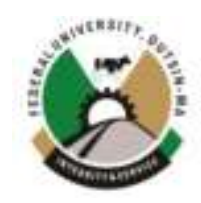

\title{
POSTPARTUM CONCENTRATIONS OF ESTRADIOL AND PROGESTERONE IN THREE GENOTYPE OF SHEEP FED VARYING LEVELS OF PROTEIN
}

\author{
Hassan, A. M., "Nasir, M., Abdullahi, A. Y. and Zango, M. H. \\ Department of Animal Science, Faculty of Agriculture and Agricultural Technology, Kano University of Science and \\ Technology, Wudil.
}

*Corresponding author's email: alhassanhassan66@ gmail.com mudassirnasir3@ gmail.com +2348036084530

\begin{abstract}
The study aims to evaluate the effects of feeding different protein levels on the resumption of postpartum ovarian activity by measuring serum estradiol (E2) and progesterone (P4) concentrations bi-weekly starting one week postpartum in three genotypes of sheep (Yankasa, Uda and Balami). Eighteen (18) multiparous sheep with aged range of $2.5-3$ years old consisting of six (6) each of Yankasa, Uda and Balami breeds were divided into three groups and reared on different protein concentrations. The protein concentrations were $15.2 \%$ (high), 9.5\% (medium) and 6.5\% (low). Results showed a gradual increase of estradiol in both Yankasa and Uda breeds fed low protein diet from $100-3000$ concentration. However, Uda breed had the highest value of estradiol when both medium and high protein diets were fed to the three genotypes of sheep. Nevertheless, Yankasa sheep had more consistent values of progesterone when fed low protein diet compared to Balami and Uda. Also Uda breed recorded the highest progesterone values in both medium and high protein diets among the three genotypes followed by Yankasa sheep. All the three genotypes returned to estrous earlier on high protein concentration followed by those on medium protein level. It is concluded that increase protein concentration hastened resumption of ovarian cyclicity and thereby leading to increase fertility in sheep.
\end{abstract}

Keywords: Sheep, genotype, postpartum, estradiol, progesterone, protein level

\section{INTRODUCTION}

Nutrition and reproduction interaction has been known to have important implications for the reproductive performance of farm animals (Bindari et al., 2013). Nutrition plays an important role as it affects directly or indirectly the physiological and reproductive performance of animals. Farm animals undergo a period following parturition when they are not able to become pregnant. The delay in resumption to reproductive activities is a natural way of ensuring that the dam has sufficient resources to meet her own demand and that of her newborn offspring (Gordon, 2004). Many factors influence the resumption of ovarian activities in postpartum ewes, such factors are lambing season, breed, nutrition, lactation, frequency of and intensity of suckling (Ascari et al., 2016). The effect of feeding high energy diets on reproduction is well documented; however, few studies have verified this with protein-rich diets. A study was conducted by Socheh (2012) in Kejobong goats divided into two groups. Group one (non-flushing) was given ration with an energy content of $1.35 \mathrm{Mcal} / \mathrm{Kg} \mathrm{ME}$ and group two (flushing) received $3.06 \mathrm{Kcal} / \mathrm{Kg} \mathrm{ME}$ and then injected twice with a sterile solution of Lutalyse ${ }^{\mathrm{R}}$ (Dinoprost tromethamine) at a dose of $5 \mathrm{mg} / \mathrm{head}$. At the time of estrus, concentration of estrogen in flushing group was significantly higher than the non-flushing group. Khanum et al. (2008) reported that at estrus period, the concentration of estrogen reaches the highest value of $7.70 \pm 1.70 \mathrm{pg} / \mathrm{ml}$ whereas progesterone begins to rise from the basal $0.010 \pm 0.6 \mathrm{ng} / \mathrm{ml}$ on day 0 up to $3.00 \pm 0.90 \mathrm{ng} / \mathrm{ml}$ on day 6 of estrus cycle and reaches peak value of $7.70 \pm 0.60 \mathrm{ng} / \mathrm{ml}$ on day 12 . High energy diets stimulate follicular development (Webb et al., 2004), however, there is still controversy on the effects of diets rich in protein, rumen-degradable protein and non-protein nitrogen on ovarian follicular dynamics (Laven et al., 2004; Alves et al., 2011). The effect of dietary protein on reproduction is complex (Surai, 1999), prolonged inadequate protein intake has been reported to reduce reproductive performance. More recently it has been found that reproductive performance may be impaired if protein is fed in amounts that greatly exceed the animals requirement. Overfeeding of protein during the breeding season and early gestation, particularly if the rumen receives an inadequate supply of energy may be associated with decrease in fertility (Dunn and Moss, 1992). Blood progesterone concentration can be influenced by feed intake and possibly, by excess protein in the diet. An inverse relationship was observed in ewes between the dry matter intake and plasma progesterone concentration (O'Callaghan et al., 2000). In ewe, the ovarian steroids (progesterone (P4) and estradiol (E2)) provide feedback control of reproductive neuroendocrine function, with each hormone affecting both the tonic and surge modes of GnRH and LH secretion (Ascari et al., 2016).

The objective of this study was to assess the effect of feeding different protein concentrations on the level of estradiol and progesterone in three genotype of sheep.

\section{MATERIALS AND METHODS}

\section{Study Area}

The study was conducted at the Teaching and Research Farm of the Department of Animal Science, Faculty of Agriculture and Agricultural Technology, Kano University of Science and Technology, Wudil. Wudil lies between longitude $8^{0} 58^{\prime}$ East and latitude $11^{0} 35^{\prime}$ North at an altitude of $403 \mathrm{~m}$ above sea level. The average annual rainfall ranges from 850 to $870 \mathrm{~mm}$, minimum and maximum temperature is $26^{\circ} \mathrm{C}$ and $33^{\circ} \mathrm{C}$, respectively (Olofin et al., 2008). 


\section{Experimental Animals}

Eighteen (18) adult sheep ( $2-3$ years old) consisting of 6 each of Yankasa, Uda and Balami breeds were used. Animals were treated against internal and external parasites using Ivotek super ${ }^{\circledR}$ (Ivermectin + Clorsulon) at dose of $200 \mu \mathrm{g} / \mathrm{kg}$ body weight. They were also vaccinated against pnuemo-enteritis complex [peste-des-petits ruminants (PPR)] at a dose of 1 ml/animal subcutaneously. Experimental animals were quarantined for two (2) weeks and; water and mineral licks were provided ad libitum. They were kept in individual pens in a common shed to eliminate any variations attributed to environmental and management changes.

\section{Experimental Procedure}

The eighteen sheep (18) were randomly divided into three groups of six animals per treatment. Each group consists of two (2) Yankasa, two (2) Uda and two (2) Balami sheep. Animals in group 1, 2 and 3 were fed with $15.2 \%$ (high protein), $9.5 \%$ (medium protein) and $6.5 \%$ (low protein), respectively (Table 1). A completely randomized design with $3 \times 3$ factorial arrangement using individual breed as experimental unit with 3 protein levels was used and blood sample was taken a week after lambing up to two weeks after postpartum estrus to determine the level of estradiol and progesterone.

Determination of Proximate Composition of Experimental Diets

Samples of the experimental diets were collected and chemically analyzed to determine their proximate composition according to AOAC (1990) to obtain the dry matter (DM), ash (minerals) and total nitrogen (to determine crude protein), crude fibre (CF), ether extract (EE) and nitrogen free extract (NFE).

\section{Hormonal Assay (estradiol and progesterone)}

Eighteen (18) animals (6 from each group) were used for determination of serum estradiol and progesterone by collecting blood samples $(10 \mathrm{ml})$ via jugular vein using sterile syringe and needle and emptied into sterile sample bottle without anticoagulant, starting one week after lambing until two weeks after appearance of the first postpartum estrus. The blood samples were allowed to clot and then centrifuged at 3,000 rpm for 20 minutes. The serum samples were harvested and stored at $-20^{\circ} \mathrm{C}$ until assay. Estradiol $(\mathrm{pg} / \mathrm{ml})$ and progesterone $(\mathrm{ng} / \mathrm{ml})$ concentrations were determined using enzyme-linked immunosorbent assay (ELISA) method.

\section{Statistical Analysis}

Data generated were coded and then analyzed using simple descriptive statistics in form of graphical presentation using Excel (2016).

\section{RESULTS AND DISCUSSION}

A lot of studies were carried out on the resumption of postpartum ovarian activities and estrus seasonality in temperate breed (Rubianes et al., 1996). However, there is little information with regard to semi-arid areas. It is a well-known fact that systemic progesterone concentration greater than $1 \mathrm{ng} / \mathrm{ml}$ are associated with corpus luteum or luteinized follicle (Berandinelli et al., 2001). Nutrition has direct or indirect effects on the physiological and reproductive performance of animals. In the present study, the result of low protein diet on estradiol (E4) in three genotype of sheep (Figure I) indicated that Balami had the highest value from 20 to 100 concentration level after which it decreases up to 3000 concentration level whereas Yankasa breed had the highest value at 500 concentration level compared to the other breed. However, Uda breed had almost similar value at different concentration levels which were relatively higher than those of Balami breed. In other words, Yankasa breed had the highest value of E4 at 500 concentration level followed by Uda. The least value was recorded in Balami breed.

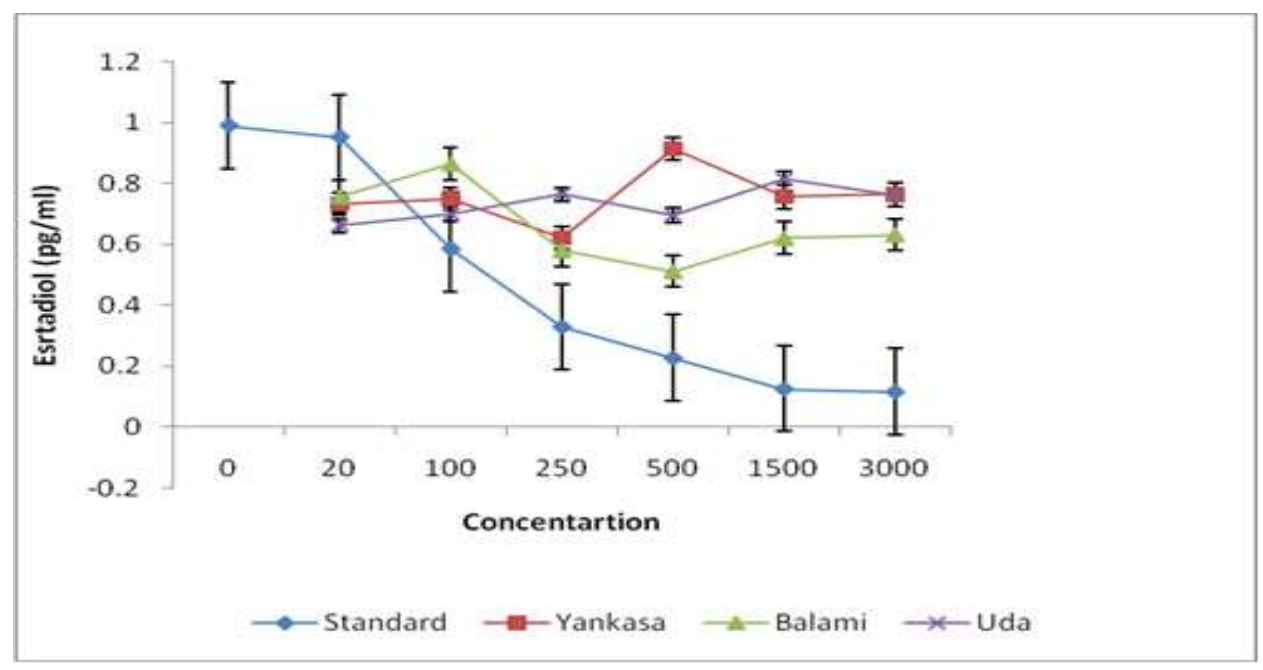

Figure I: Effect of low protein diet on estradiol (pg/ml) levels in three genotype of sheep

However, in medium protein diet (Figure II) Uda breed recorded the highest value of E4 from 250 to 1500 concentration level followed by Yankasa. The least value of E4 was recorded in Balami breed. 


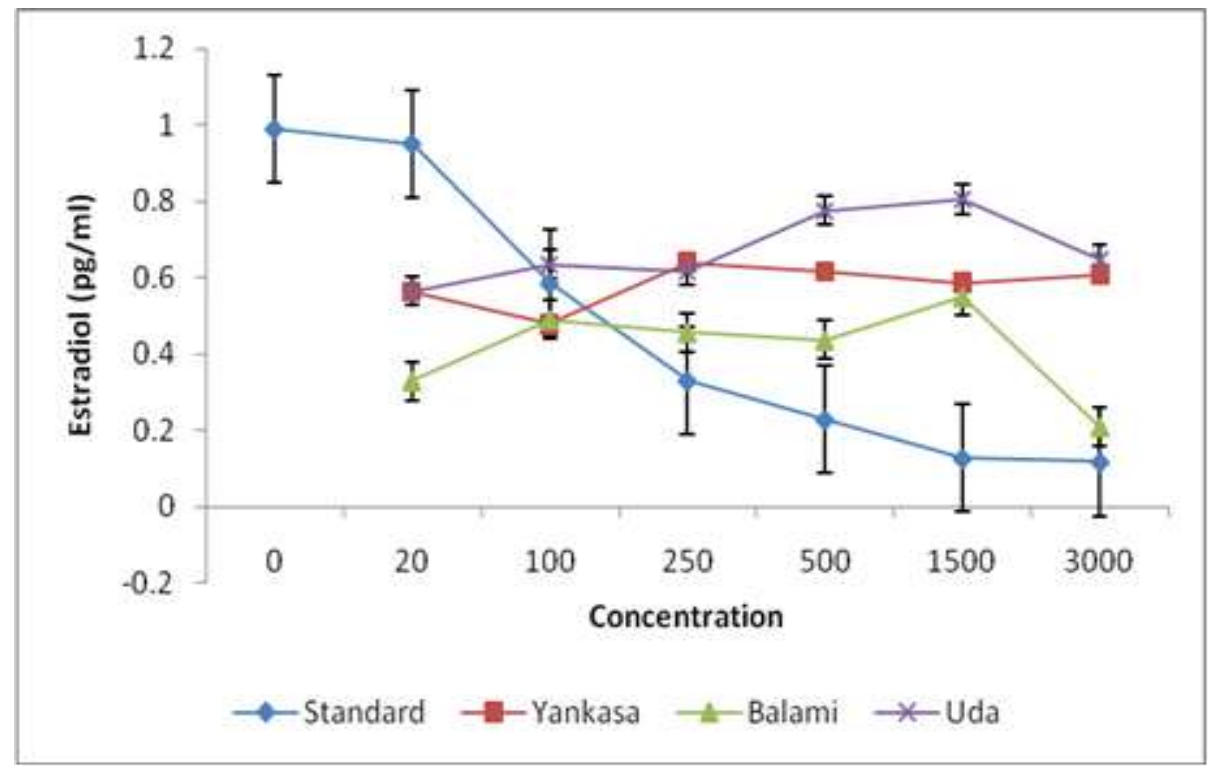

Figure II: Effect of medium protein diet on extradiol $(\mathrm{pg} / \mathrm{ml})$ levels in three genotype of sheep

In high protein diet (Figure III) Uda breed recorded the highest value of E4 from 250 to 1500 concentration levels among the three genotypes followed by Balami breed from 20 to 1500 concentration levels. The least was recorded in Yankasa breed.

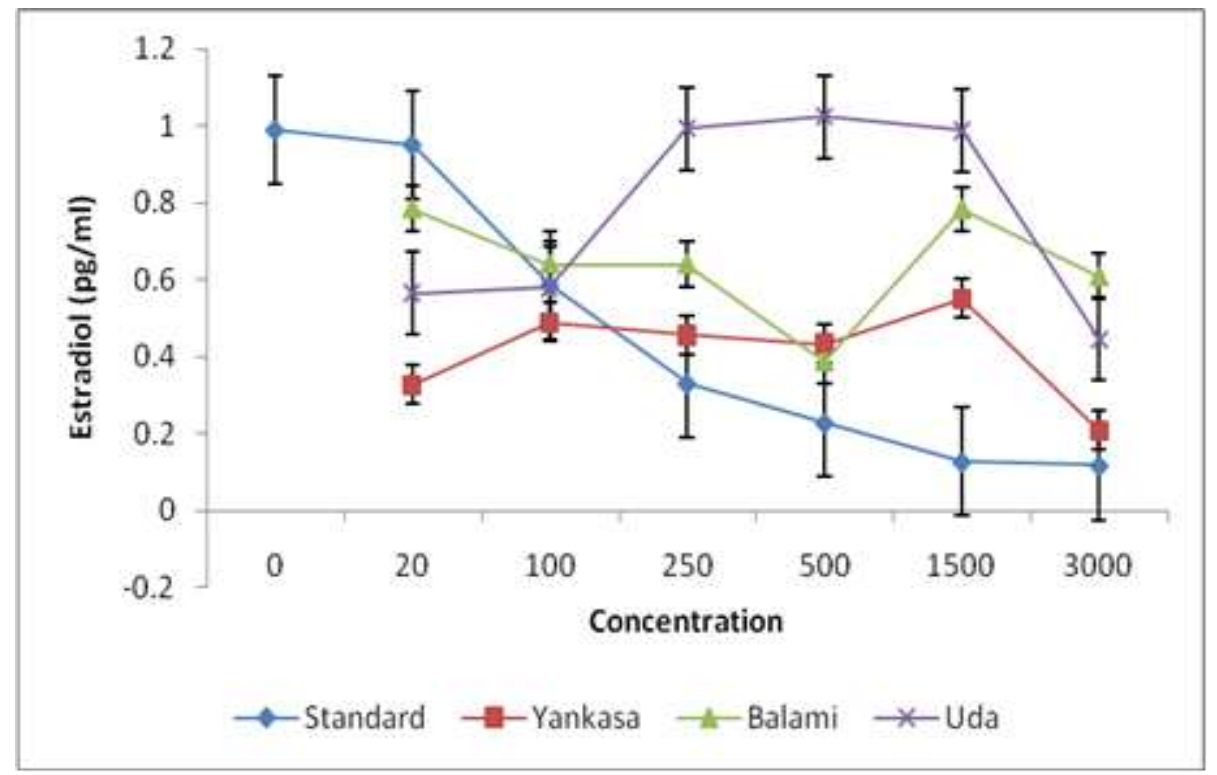

Figure III: Effect of high protein diet on extradiol (pg/ml) levels in three genotype of sheep

On the other hand, the effect of progesterone level on low protein diet (Fig IV), the result indicated that Yankasa breed had the best concentration levels at $0.3,15$ and 60 , followed by Balami breed which had the highest concentration at 5 . The least values were obtained in Uda breed at 2 and 60 concentration levels. 


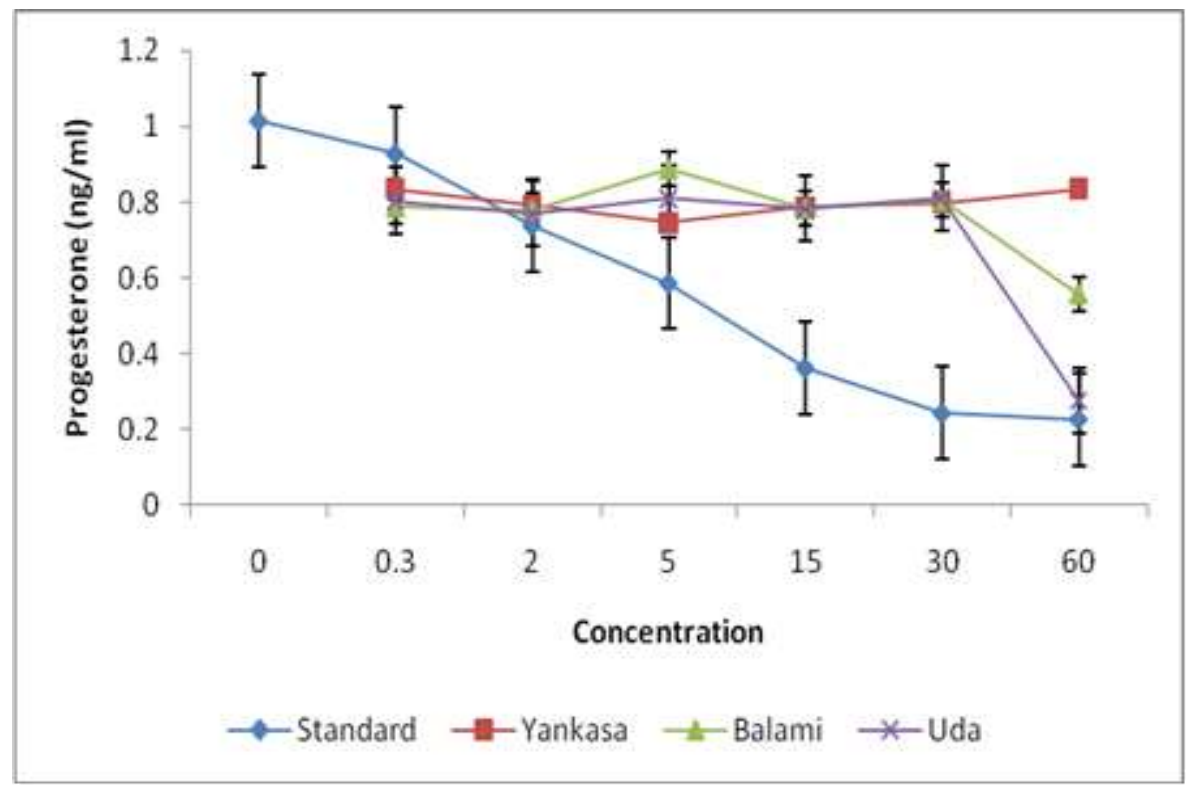

Figure IV: Effect of low protein diet on progesterone (ng/ml) levels in three genotype of sheep

In medium protein diet (Figure V) Uda breed had the best P4 level at all different concentration levels followed by Yankasa breed, whereas the least values were obtained in Balami breed.

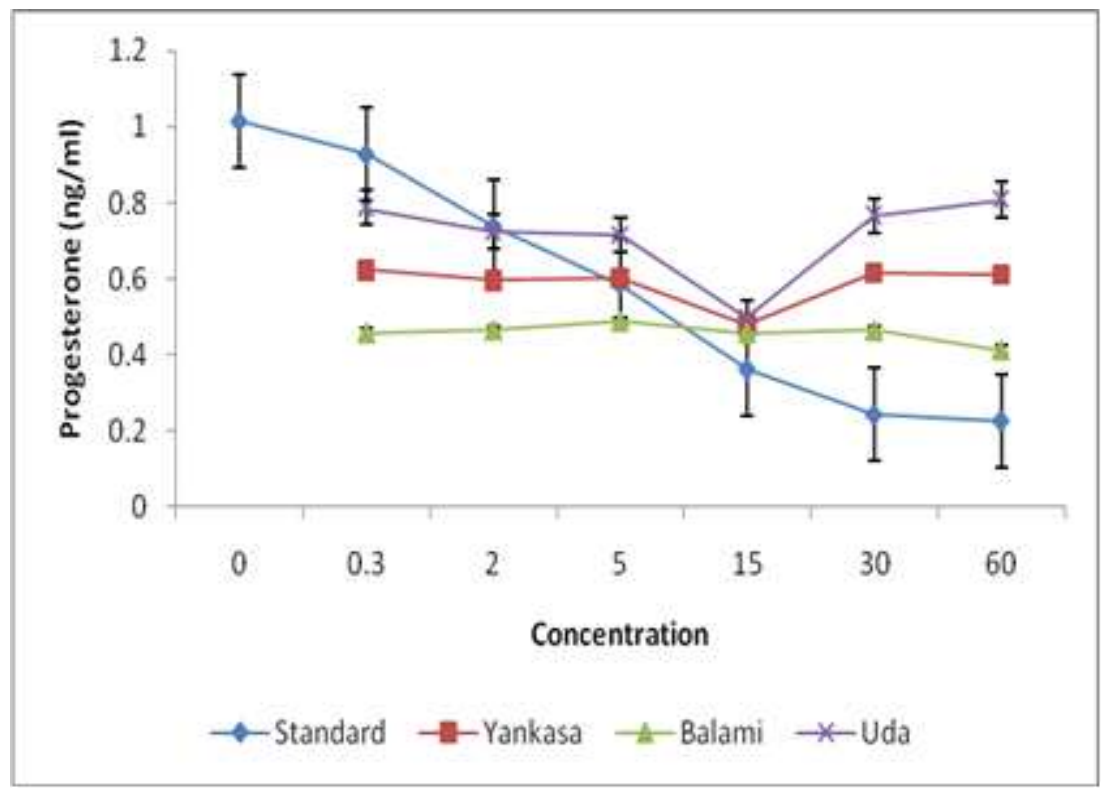

Figure V: Effect of medium protein diet on progesterone $(\mathrm{ng} / \mathrm{ml})$ levels in three genotype of sheep

Nevertheless, in high protein diet (Figure VI) Uda breed had the best P4 level from 0.3 up to 30 concentration levels followed by Balami breed which had a sharp drop at 5 concentration levels. The least values were recorded in Yankasa breed which had sharp increase at 60 concentration level. 


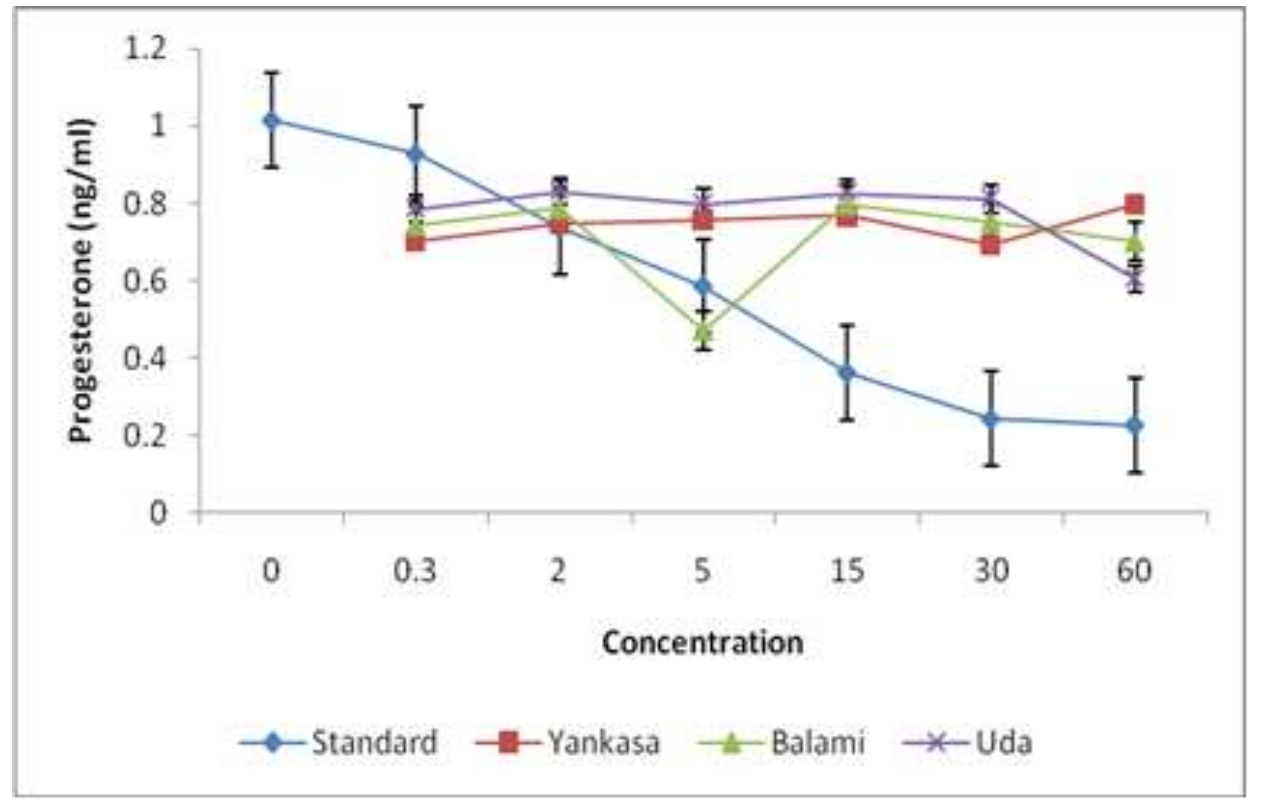

Figure VI: Effect of high protein diet on progesterone (ng/ml) levels in three genotype of sheep

Blood concentration of progesterone is considered a good indicator of luteal function during postpartum period as progesterone is one of the major steroid synthesize by corpus luteum (Medan and El-Daek, 2015). It is recognized that systemic progesterone concentrations greater than $1 \mathrm{ng} / \mathrm{ml}$ are related with presence of corpus luteum or luteinized follicle (Berardinelli et al., 2001). Ovarian estradiol plays a main role in establishing the timing of uterine receptivity to the development of embryo and embryo survival (Miller and Moore, 1976; Ozturk and Demir, 2010). It is observed in bovine that, estrus is initiated after a rise in circulating estradiol level (Allrich, 1994). Circulating concentrations of estradiol during the pre-ovulatory period can influence the establishment and maintenance of pregnancy by altering the uterine environment (Miller and Moore, 1976; Miller et al., 1977).

In the present study, Yankasa and Uda breeds had shown a gradual increase of estradiol on low protein diet compared to Balami. However, Uda breed had the highest value of estradiol in both medium and high protein diets. Similarly, Uda breed had the highest value of progesterone in both medium and high protein diets. While Yankasa breed had best concentration of progesterone on low protein diet compared to Balami and Uda breeds. Khanum et al. (2008) who worked on progesterone and estrogen profile during the estrus cycle and gestation in Dwarf goats reported that at estrus period, the concentration of estrogen reaches the highest value, whereas progesterone begins to rise from the basal on day 0 and reaches peak value on day 12 . However, Medan and El-Daek (2015) reported low serum progesterone level on all examined Barbary ewes showed a state of ovarian inactivity during first 70 days after parturition.

Interestingly, our present findings have shown that all the three genotype of sheep fed on high protein diets (Table 2) hastened resumption of ovarian cycle between lambing and estrus resumption; followed by those fed on medium protein diets, while those fed on low protein diets had longest estrus resumption periods, this agreed with the report of Ramzi et al.
(2017) in Ouled Djellal ewes where the first rise of the mean progesterone level greater than $1 \mathrm{ng} /$ mlappeared at sixth week post lambing in winter when feed was very much available. Lamming et al. (1974) attributed prolong postpartum luteal activity due to high prolactin hormone observed on the few weeks postpartum. Likewise, delayed onset of the ovarian activity might be due to negative energy or protein balance. Ewes nursing lambs were often in negative energy balance during first month of lactation (Robinson et al., 1979). Hileman et al. (2011) added that interval from parturition until the first ovulation is greatly influenced by season. Though, there is still controversy on the effects of diets rich in protein, rumendegradable protein and non-protein nitrogen on ovarian follicular dynamics (Laven et al., 2004; Alves et al., 2011). In his research, Webb et al. (2004) emphasized that high energy diets stimulate follicular development. Earlier, Surai, (1999) said the effect of dietary protein on reproduction is complex as prolonged inadequate protein intake has been reported to reduce reproductive performance.

\section{CONCLUSION}

Based on our present findings, we concluded that among the three genotype of sheep, Uda breed had promoted positively on both medium and high protein diets, while Yankasa breed had more consistent on low protein diet. Therefore, feeding varying level of proteins stimulated a positive effect, as increased reproductive parameters such as resumption of ovarian activity, postpartum based on concentrations of estradiol and progesterone examined. The study also reaffirmed that a quantitative ELISA technique could be used to accurately determine the steroid profile and monitor the detection of resumption of ovarian cyclicity of animals and hence to successfully breed them. 


\section{ACKNOWLEDGMENT}

This work was funded by Tertiary Education Trust Fund TETFUND under Institutional Based Research (IBR, 2018). The Authors would like to appreciate Department of Animal Science, KUST Wudil and Faculty of Veterinary, ABU Zaria for supports while conducting the research.

\section{CONFLICT OF INTERESTS}

The authors declare that there is no conflict of interests regarding the publication of this paper.

\section{REFERENCES}

Alves, N. G.; Torres, C. A. and Guimarães, J. D. (2011). Effect of urea in the diet on ovarian follicular dynamics and plasma progesterone concentration in Alpine goats.Revista Brasileira de Zootecnia, 40, 1512 - 1518.

Allrich, R. D. (1994) Endocrine and neural control of estrus in dairy cows. J Dairy Sci 77: 27382744.

Ascari, I. J., Alves, N. G., Alves, A. C., Garcia, I. F. F. and Junqueira, F. B. (2016). Resumption of cyclic ovarian activity in postpartum ewes: A review seminar: Ciencias Agrarias (Londarina), 37(2): 1101 - 1115.

Berardinelli, J.G., Wenig, J., Burfening, P.J., Adair, R. (2001) Effect of excess degradable intake protein on early embryonic development, ovarian steroid and blood urea nitrogen on days 2 , 3, 4 and 5 of the estrus cycle in mature ewes. J. Anim. Sci. 79: $193-199$

Bindari, Y. R., Sulochana, S., Nabaraj, S. and Gaire, T. N. (2013). Effect of nutrition on reproduction-A review Advances in Applied Science Research, 4(1) : 421-429.

Dunn, T. G. and Moss, G. E. (1992). Effects of nutrients deficiencies and excesses on reproductive efficiency of livestock. Journal of Animal Science, 70, 1580 - 1593.

Gordon, I. (2004). Reproductive Technology in Farm Animals CABI Publishing, Pp 347.

Hileman, M.S., McManus, C.J., Goodman, R.L., Jansen, H.T. (2011). Neurons of the lateral preoptic area/rostral anterior hypothalamic area are required for photoperiodic inhibition of estrous cyclicity in sheep. Biil. Reprod. 85: 1057 - 1065

Khanum, S. A., M. Hussain, and R. Kausar. (2008). Progesterone and estrogen profile during the estrus cycle and gestation in Dwarf goats (Capra hircus). Pakistan Veterinary Journal, 28: 1 - 4 .

Lamming, G.H., Moeley, S.R., McNeilly, J.R. (1974). Prolactin release in the sheep. J. Reprod. Fer. 40:151 - 168.

Laven, R. A.; Dawuda, P. M. and Scaramuzzi, R. J. (2004). The effect of feeding diets high in quickly degradable nitrogen on follicular development and embryo growth in lactating Holstein dairy cows. Animal Reproduction Science, 84(1/2): 41 - 52.

Medan, M.S., El-Daek, T. (2015) Uterine involution and progesterone level during postpartum period in Barbary ewes in north Libya. Open Veterinary Journal 5 (1): 18-22

Mekonnin, A.B., Howie, A.F., Riley, S.C., Gidey, G., Tegegne, D.T., Desta, G., Ashebir, G., Gebrekidan, B., Harlow, C.R. (2017) Serum, milk, saliva and urine progesterone and estradiol proles in crossbred (Zebu x Holstein Friesian) dairy cattle. Anim Husb Dairy Vet Sci 1: DOI: 10.15761/AHDVS.1000118

Miller, B.G., Moore N.W. (1976) Effects of progesterone and oestradiol on endometrial metabolism and embryo survival in the ovariectomized ewe. Theriogenology 6: 636.

Miller, B.G., Moore N.W., Murphy L, Stone G.M. (1977) Early pregnancy in the ewe: effects of oestradiol and progesterone on uterine metabolism and on embryo survival. Aust J Biol Sci 30: 279-288.

O’Callaghan, D., Yaakub, H., Hyttel, P., Spicer, L.J., Boland, M.P. (2000). Effect of nutrition and superovulation on oocyte morphology, follicular fluid compositionand systemic hormone concentration in ewes. J. Reprod. Fertil. 18:303 - 313.

Olofin, E. A., Nabegu, A. B. and Dambazau, A. M. (2008). Wudil within Kano region: A geographical synthesis, $1^{\text {st }}$ edition, Adamu Joji Publishers, Kano State, Nigeria, Pp 134 -138.

Ozturk, S., Demir, R. (2010) Particular functions of estrogen and progesterone in establishment of uterine receptivity and embryo implantation. Histol Histopathol 25: 1215-1228.

Ramzi, L., F. Farida Afri-Bouzebda and Zoubir B. (2017). Resumption of ovarian cyclicity during postpartum in winterlambing Ouled Djellel ewes in Algerian semi-arid area. Global Veterinaria, 18(1): 27 - 30.

Rubianes, E., Ugerfeld, R., Vinoles, C., Carbajal, B., De Catro, T., Ibarra, D. (1996). Uterine involution time and ovarian activities in weaned and suckling ewes. Can. J. Anim. Sci. 76:153-155

Socheh M. (2012). Pengaruh pakan berbasis ketela pohon terhadap kinerja reproduksi (pada pemberian secara flushing) dan kinerja produksi kambing Kejobong. Disertasi. Program Pascasarjana. Fakultas Peternakan, Universitas Gajah Mada Yogyakarta.

Surai, P. F. (1999). Vitamin E in avian reproduction. Poultry Avian Biology Rev. 10, $1-60$.

Webb, R.; Garnsworthy, P. C. Gong, J. G., Amstrong, D.G. (2004). Control of follicular growth: local interaction and nutrition influences Journal of Animal Science 82: E63 - E74 
Table 1: Ingredients composition of the experimental diets

\begin{tabular}{llll}
\hline Ingredients $(\mathrm{kg})$ & Low protein & Medium protein & High protein \\
\hline Cowpea & 16.81 & 29.91 & 20.00 \\
Rice bran & - & - & 20.00 \\
Wheat bran & 12.99 & 19.89 & 56.81 \\
Cotton seed cake & - & - & 2.99 \\
Salt & 0.2 & 0.20 & 0.20 \\
Sorghum chaff & 70 & 50.00 & - \\
Calculated analysis & & & $15.2 \%$ \\
Crude Protein & $6.5 \%$ & $9.5 \%$ & \\
\hline
\end{tabular}

Table 2: Estrous resumption date in three genotype of sheep

\begin{tabular}{|c|c|c|c|c|c|c|c|c|c|}
\hline \multirow[b]{2}{*}{ Breed } & \multicolumn{2}{|c|}{ Low protein diet $(6.5 \%)$} & \multirow[b]{2}{*}{ Days } & \multicolumn{2}{|c|}{ Medium protein diet $(9.5 \%)$} & \multicolumn{4}{|c|}{ High protein diet $(15.2 \%)$} \\
\hline & Lambing & Resumption & & Lambing & Resumption & Days & Lambing & Resumption & Days \\
\hline Uda & $3 / 1 / 18$ & $4 / 4 / 19$ & 63 & $6 / 2 / 19$ & $24 / 3 / 19$ & 46 & $7 / 5 / 19$ & $4 / 6 / 19$ & 28 \\
\hline Balami & $9 / 3 / 19$ & $23 / 5 / 19$ & 76 & $21 / 3 / 19$ & $10 / 5 / 19$ & 50 & $5 / 4 / 19$ & $26 / 4 / 19$ & 21 \\
\hline Yankasa & $24 / 2 / 19$ & $19 / 4 / 19$ & 54 & $23 / 2 / 19$ & $16 / 4 / 19$ & 52 & $1 / 4 / 19$ & $25 / 4 / 19$ & 24 \\
\hline
\end{tabular}

